\title{
DEHYDROGENATION OF HYDRAZINE HYDRATE USING NiCo BIMETALLIC CATALYST SUPPORTED ON NATURAL ZEOLITE (ZA), Z-NaY, Z-HY, $\mathrm{Al}_{2} \mathrm{O}_{3} \mathrm{AND}^{\mathrm{TiO}_{2}}$
}

\author{
M. Ridwan ${ }^{1, \bowtie}$, D. Suhanda ${ }^{2}$, I. Aziz ${ }^{2}$ and I. Abdullah ${ }^{1}$ \\ ${ }^{1}$ Department of Chemistry, Faculty of Mathematics and Natural Sciences, Universitas Indonesia, \\ Depok 16424, Indonesia \\ ${ }^{2}$ Department of Chemistry, Faculty of Science and Technology, Syarif Hidayatullah State \\ Islamic University Jakarta, Jakarta 15412, Indonesia \\ ${ }^{\bowtie}$ Corresponding Author: muhammad.ridwan@sci.ui.ac.id
}

\begin{abstract}
Hydrogen can be produced by dehydrogenation reaction of hydrazine hydrate with help of catalyst material. This study aims to investigate the effect of different catalyst support which is loaded with NiCo bimetallic catalyst toward the dehydrogenation reaction of hydrazine hydrate. Catalyst characterization was carried out using XRD, SAA, and XRF. The catalyst obtained was tested for its catalytic activity through the dehydrogenation reaction of hydrazine hydrate. Surface area analysis was performed for natural zeolite, zeolite $\mathrm{NaY}$, zeolite $\mathrm{HY}$ with the value of $40.99 \mathrm{~m}^{2} / \mathrm{g}, 88.94$ $\mathrm{m}^{2} / \mathrm{g}, 162.12 \mathrm{~m}^{2} / \mathrm{g}$, respectively. NiCo metal alloys impregnated on ZA, Z-NaY, Z-HY, $\mathrm{Al}_{2} \mathrm{O}_{3}$, and $\mathrm{TiO}_{2}$ supports produce diffraction patterns at angles of $44.5^{\circ}, 51.7^{\circ}$ and $76.3^{\circ}$ with low intensity. The surface area decreases after the $\mathrm{NiCo}$ was impregnated on the catalyst support. $\mathrm{NiCo}(1: 3) / \mathrm{TiO}_{2}$ catalyst produced the maximum conversion and the best catalyst activity which is $29.71 \%$ for \pm 5 minutes with a TOF of $357.79 \mathrm{~h}^{-1}$ and activation energy of 47.33 $\mathrm{kJ} / \mathrm{mol}$.
\end{abstract}

Keywords: Hydrazine Dehydrogenation, Bimetallic, $\mathrm{TiO}_{2}$, Zeolite Y, Hydrogen Generation.

RASĀYAN J. Chem., Vol. 14, No.3, 2021

\section{INTRODUCTION}

Hydrogen is a clean and efficient renewable energy source, due to its combustion only produces water vapor and energy. In addition, the gravimetric energy density of hydrogen reaches $33.3 \mathrm{kWh} / \mathrm{kg}$ and the resulting calorific value is three times greater than gasoline. ${ }^{1}$ A large number of materials for the formation of hydrogen such as metal hydrides, and molecular hydrides have been studied before, but the development of methods using materials in the form of molecular hydrides is still not widely known. However, materials in the form of molecular hydrides have the potential to have a high hydrogen content. One of the molecular hydrides that can be used is hydrazine hydrate. ${ }^{2}$ Hydrazine hydrate $\left(\mathrm{N}_{2} \mathrm{H}_{4} \cdot \mathrm{H}_{2} \mathrm{O}\right)$ has a higher hydrogen content $\left(8.0 \%\right.$ ) compared to $\mathrm{Mg}_{2} \mathrm{NiH}_{4}$ metal hydride $(3.60 \%){ }^{3}$ The metal used as a catalyst in the hydrazine hydrate dehydrogenation reaction can come from the transition group and the noble metal and many researchers recently developed a bimetallic catalyst. ${ }^{4-6}$

Yang, et al., mentioned that MIL-101 (Metal-organic Framework Based)-supported Ni monometal catalyst showed low activity of hydrogen generation from $\mathrm{N}_{2} \mathrm{H}_{4}$ at $323 \mathrm{~K}$, and released 4.29 equiv $\left(\mathrm{H}_{2}+\mathrm{N}_{2}\right)$ hydrogen per $\mathrm{N}_{2} \mathrm{H}_{4}$ for 170 minutes. ${ }^{2}$ In addition, the NiFe / MIL-101 bimetallic catalyst showed higher catalyst activity and selectivity compared to monometals released 4.89 equiv $\left(\mathrm{H}_{2}+\mathrm{N}_{2}\right)$ hydrogen per $\mathrm{N}_{2} \mathrm{H}_{4}$ for 124 minutes. Men, et al., studied $\mathrm{NiFe}$ catalyst with a variation of 1: 3 (Ni: Fe) supported by reduced graphene oxide ( $\mathrm{r}-\mathrm{GO})$ resulted in a higher conversion with the best catalyst activity compared to variations 3: 1 and 1: 1 (Ni: Fe). ${ }^{7}$ Chen, et al., stated that Ni-based catalysts showed superior catalytic activity and high selectivity to dehydrogenation of hydrazine hydrate for hydrogen formation. ${ }^{8}$ Singh, et al., also observed that the amorphous form of $\mathrm{CoB}_{0.5-0.01}$ nanocatalyst showed much better catalyst activity at room temperature with a hydrogen selectivity of $41.8 \% .{ }^{9}$ The use of metal oxides $\left(\mathrm{Al}_{2} \mathrm{O}_{3}, \mathrm{CeO}_{2}, \mathrm{La}_{2} \mathrm{O}_{3}\right.$, and $\left.\mathrm{TiO}_{2}\right)$ as supports can significantly improve catalyst performance by providing large metal surface area and strong metal-support interactions. ${ }^{10}$ 
Much research was done using natural zeolite as multifunctional material. ${ }^{11,12}$ Aubakirov mentioned that modifying natural zeolite with molybdenum gives high catalytic activity on thermo-catalytic processing of polymer waste. ${ }^{13}$ The acid site of type $\mathrm{Y}$ zeolite also serves as an active site for hydrogenation, hydrocracking and other reactions, this makes the combination of metal and Y type zeolite support to produce a catalyst that is multifunctional. ${ }^{14}$

This study focused to examine the effect of zeolite acid sites on hydrazine hydrate dehydrogenation reactions. In addition, catalyst synthesis was carried out with several parameters including variations in the ratio of NiCo metal supported by $\mathrm{Al}_{2} \mathrm{O}_{3}$ and variations of the catalyst supports such as $\mathrm{TiO}_{2}$, natural zeolite, $\mathrm{Z}-\mathrm{NaY}$ and Z-HY. The catalytic activity and the conversion of hydrazine hydrate to hydrogen are determined by the dehydrogenation reaction.

\section{EXPERIMENTAL}

\section{Material and Methods}

The materials used in this study were nickel (II) chloride hexahydrate $\left(\mathrm{NiCl}_{2} \cdot 6 \mathrm{H}_{2} \mathrm{O}\right)$, cobalt (II) chloride hexahydrate $\left(\mathrm{CoCl}_{2} \cdot 6 \mathrm{H}_{2} \mathrm{O}\right.$, Sigma Aldrich), sodium borohydrate $\left(\mathrm{NaBH}_{4}\right.$, Daejung Chemical), sodium hydroxide ( $\mathrm{NaOH}$, Samchun Chemicals), hydrazine monohydrate $\left(\mathrm{N}_{2} \mathrm{H}_{4} \cdot \mathrm{H}_{2} \mathrm{O}\right.$, Sigma Aldrich), aluminum oxide $\left(\mathrm{Al}_{2} \mathrm{O}_{3}\right.$, Alfa Aesar), natural zeolite, $\mathrm{TiO}_{2}$ rutile powder, aquadest and deionized water (DI).

\section{Preparation of Zeolite}

$\mathrm{NaY}$ Zeolite was prepared using a modified hydrothermal fusion method with a ratio of 1:2.4 and heated in a furnace at a temperature of $550^{\circ} \mathrm{C}$ for 4 hours. After cooling to room temperature $40 \mathrm{~mL}$ of water was added and allowed for 12 hours. The mixed solution was put into a Teflon-coated stainless-steel autoclave to carry out the hydrothermal process at $100{ }^{\circ} \mathrm{C}$ for 8 hours. The sample was washed with a solution of hydrochloric acid $(\mathrm{HCl} 1 \mathrm{M})$ and aquadest to remove the absorbed alkaline to a neutral $\mathrm{pH}$. The product was filtered and dried at $150^{\circ} \mathrm{C}$ in an oven, to form zeolite $\mathrm{NaY} .{ }^{15}$ Zeolite $\mathrm{NaY}$ obtained was put into a solution of $\mathrm{NH}_{4} \mathrm{NO}_{3}(1 \mathrm{M})$ with a ratio of $1: 10$. Then it was heated at $100{ }^{\circ} \mathrm{C}$ for 2 hours and washed with distilled water to a $\mathrm{pH}$ of $6-8$, followed by drying for 2 hours at $105^{\circ} \mathrm{C}$. The material was calcined at $550{ }^{\circ} \mathrm{C}$ for 2 hours.

\section{Synthesis of Bimetal Catalyst by In-situ Impregnation.}

Ni monometal was loaded into different support materials ( $\mathrm{ZA}, \mathrm{Z}-\mathrm{NaY}, \mathrm{Z}-\mathrm{HY}, \mathrm{Al}_{2} \mathrm{O}_{3}$ and $\mathrm{TiO}_{2}$ ) with the ratio between metal and catalyst support 10:90 w/w was synthesized by in-situ impregnation method. Briefly, $2.43 \mathrm{~g}$ of $\mathrm{NiCl}_{2} .6 \mathrm{H}_{2} \mathrm{O}$ was dissolved into $20 \mathrm{~mL}$ of $\mathrm{DI}-\mathrm{H}_{2} \mathrm{O}$, adding an amount of $5.4 \mathrm{~g}$ of material supports, stirred and heated at $100{ }^{\circ} \mathrm{C}$ until dried and then calcined at $400{ }^{\circ} \mathrm{C}$ for 2 hours. Monometal catalyst $\mathrm{Co} / \mathrm{Al}_{2} \mathrm{O}_{3}$ was made with the same method and support-metal composition as the above method. An amount of $2.4224 \mathrm{~g}$ of $\mathrm{CoCl}_{2} \cdot 6 \mathrm{H}_{2} \mathrm{O}$ was dissolved into $20 \mathrm{ml}$ of $\mathrm{DI}-\mathrm{H}_{2} \mathrm{O}$, stirred and heated at $100{ }^{\circ} \mathrm{C}$ until dried and then calcined at $400^{\circ} \mathrm{C}$ for 2 hours. The NiCo bimetal catalyst was made with different ratio variations which are then impregnated into the supports. The ratio variations used are 1:1, 1:3 and 3:1, where the total catalyst and the ratio of the total metal loading with the supports are the same as monometalic catalysts.

\section{Catalyst Characterization}

The instrument was used in this study were Shimadzu 700 X-Ray Diffraction (XRD), Quantachrome NovaWin version.11 Surface Area Analyzer (SAA), and JEOL Element Analyzer JSX-3211 X-Ray Fluorescence (XRF).

\section{Catalytic Activity Test}

Briefly, all catalysts that have been synthesized are subjected to a catalyst test with hydrazine hydrate dehydrogenation reaction to form hydrogen. About $0.5 \mathrm{~g}$ catalyst was put into a reactor, then $8 \mathrm{~mL}$ of DIwater was added to the reactor and the mixture was stirred. A $2 \mathrm{~mL}$ solution containing $10 \mathrm{mmol}_{\text {of }} \mathrm{NaBH}_{4}$ and $10 \mathrm{mmol}$ of $\mathrm{NaOH}$ was added and allowed to stand until bubbles disappear in the solution. Furthermore, the dehydrogenation reaction was done by adding $1 \mathrm{~mL}$ of hydrazine hydrate to the reactor using a syringe. 
During the process, the temperature of the reactor was maintained at $343 \mathrm{~K}$. The gas produced during the reaction was passed through an $\mathrm{HCl}(1 \mathrm{M})$ solution and the quantity of the gas produced was measured. The hydrogen selectivity (X) was calculated using eqn.-1 and TOF was calculated using eqn.-2.

$X=(\lambda / 3) \times 100 \%\left[\lambda=n\left(\mathrm{H}_{2}+\mathrm{N}_{2}\right) / \mathrm{n}\left(\mathrm{N}_{2} \mathrm{H}_{4} \cdot \mathrm{H}_{2} \mathrm{O}\right)\right]$

$\mathrm{TOF}=\mathrm{nH}_{2} /(\mathrm{nNiCox} \mathrm{t})$

Where $t$ is the reaction time the hydrazine hydrate reaches $50 \%$ conversion, the amount of hydrogen determined by the volume of the generated gas is $\mathrm{nH}_{2}$, and $\mathrm{n}_{\mathrm{NiCo}}$ is the amount of $\mathrm{Ni}$ and Co.

\section{RESULTS AND DISCUSSION}

Brauner-Emmett-Teller (BET) method was used to determine surface area. Another method, namely BJH adsorption was used to determine the pore size distribution of natural zeolites and synthetic zeolites, namely $\mathrm{Z}-\mathrm{NaY}$ and Z-HY, so that the SAA results can be seen in Table -1 .

Table-1: Surface Area Characterization

\begin{tabular}{l|c|c|c}
\hline \multicolumn{1}{c|}{ Catalyst } & $\begin{array}{c}\text { Surface Area } \\
\left(\mathrm{m}^{2} / \mathrm{g}\right)^{\mathrm{a}}\end{array}$ & $\begin{array}{c}\text { Total pore volume } \\
(\mathrm{cc} / \mathrm{g})^{\mathrm{b}}\end{array}$ & $\begin{array}{c}\text { Pore Diameter } \\
(\mathrm{nm})\end{array}$ \\
\hline $\mathrm{ZA}$ & 40.99 & 0.07 & 3.93 \\
\hline $\mathrm{Z}-\mathrm{NaY}$ & 88.94 & 0.26 & 5.49 \\
\hline $\mathrm{Z}-\mathrm{HY}$ & 162.12 & 0.29 & 3.55 \\
\hline $\mathrm{NiCo}(1: 3) / \mathrm{ZA}$ & 25.38 & 0.06 & 3.56 \\
\hline $\mathrm{NiCo}(1: 3) / \mathrm{Z}-\mathrm{NaY}$ & 65.84 & 0.28 & 13.22 \\
\hline $\mathrm{NiCo}(1: 3) / \mathrm{Z}-\mathrm{HY}$ & 81.40 & 0.15 & 4.87 \\
\hline $\mathrm{NiCo}(1: 3) / \mathrm{Al}_{2} \mathrm{O}_{3}$ & 5.74 & - & - \\
\hline $\mathrm{NiCo}(1: 3) / \mathrm{TiO}_{2}$ & 7.98 & - & - \\
\hline $\begin{array}{l}\mathrm{Remarks:} \text { a. } \text { Multipoint } \mathrm{BET} \\
\text { b. Total pore Volume of } \mathrm{P} / \mathrm{Po} 0.9907\end{array}$ \\
\hline
\end{tabular}

Table-1 shows surface area analysis of different samples. It shows that natural zeolites have a smaller surface area compared with zeolites $\mathrm{NaY}$ and and Z-HY with the value of $40.99,88.94$ and $162.116 \mathrm{~m}^{2} / \mathrm{g}$, respectively. This increase in the surface area indicates that the alkaline fusion process has succeeded in removing impurities and extracting $\mathrm{Si}$ in the zeolite so that it can increase the pore diameter, which results in a larger surface area. ${ }^{12,16}$ The increase in the surface area of the zeolite also affects the increase in pore volume. Therefore, the total pore volume in zeolites also increases. $\mathrm{Al}_{2} \mathrm{O}_{3}, \mathrm{TiO}_{2}, \mathrm{ZA}, \mathrm{Z}-\mathrm{NaY}, \mathrm{Z}-\mathrm{HY}$ supported NiCo (1:3) bimetal catalysts were analyzed using SAA are presented in Table -1 . It can be seen that $\mathrm{NiCo}(1: 3) / \mathrm{Al}_{2} \mathrm{O}_{3}$ and $\mathrm{NiCo}(1: 3) / \mathrm{TiO}_{2}$ has a very low surface area compared to $\mathrm{NiCo}(1: 3) / \mathrm{ZA}$. Based on the result, all catalyst support after being impregnated with $\mathrm{NiCo}(1: 3)$ experienced a significant decrease in surface area. This occurs due to the closure of the pores on the supports by transition metals.

The result of XRD analysis is shown in Fig.-1a and Fig.-1b. Figure-1a shows that the zeolite used was a clinoptilolite type, it can be seen from the diffractogram peaks at $2 \theta=9.8916^{\circ}$; and $22-30^{\circ}$. The sharp peak interpreted that clinoptilolite zeolite contains $\mathrm{SiO}_{2}$ and $\mathrm{Al}_{2} \mathrm{O}_{3}$, which are the main characteristics of zeolites. This is also following the ICDD database (International Center for Diffraction Data) 39-1383, where the diffractogram peaks show clinoptilolite-Na with the chemical formula $\mathrm{KNa}_{2} \mathrm{Ca}_{2}\left(\mathrm{Si}_{29} \mathrm{Al}_{7}\right) \mathrm{O}_{72} .24 \mathrm{H}_{2} \mathrm{O}$. Zeolite Na-faujasite $Y$ can be seen from the diffractogram peaks at $2 \theta=6.22 ; 15.60 ; 20.21 ; 23.62 ; 27.01$; and $31.36^{\circ}$, where the peaks of the diffractogram correspond to JCPDS 38-0240. The highest intensity was at a peak of $2 \theta=6.18^{\circ}$, where at that peak the characteristic of zeolite Na-Faujasite Y (Z-NaY). According to Treacy and Higgins, the first zeolite NaY peak will appear at $2 \theta=6-10^{\circ} \cdot{ }^{17}$ The zeolite NaY was modified to zeolite HY by the ion exchange method did not show the same dominant peaks as Z-NaY, the result was that the resulting intensity was lower and there was a slight shift in peaks and peaks with a low intensity previously found in Z- NaY disappeared. According to Afreen et al. Z-HY showed the diffraction peak characteristic of the FAU structure at $2 \theta=16.5 ; 19.4 ; 21 ; 24.5 ; 28 ; 32$; and $34.8^{\circ}$ with each hkl peak as 
follows: (331), (333) (440), (533), (642), (751), and (664). ${ }^{18}$ The results of this research that the resulting diffractogram 3 in Figure-1a was an amorphous HY zeolite, this suggested due to partially collapsing zeolite $\mathrm{NaY}$ framework in the zeolite $\mathrm{NaY}$ modification process, and also the release of the zeolite framework in the calcination process which freed volatile $\mathrm{NH}_{3}$ compounds from zeolite $\mathrm{NH}_{4} \mathrm{Y}$ to form more active ZHY, thus forming more amorphous.

XRD analysis was carried out on $\mathrm{NiCo}(1: 3) / \mathrm{Al}_{2} \mathrm{O}_{3}, \mathrm{NiCo}(1: 3) / \mathrm{TiO}_{2}, \mathrm{NiCo}(1: 3) / \mathrm{ZA}$-clinoptilolite, NiCo (1:3)/Z-NaY and NiCo (1:3)/Z-HY an shown in Figure -1b. The results of the crystal structure analysis of the NiCo (1: 3) $/ \mathrm{Al}_{2} \mathrm{O}_{3}$ catalyst can be seen in Figure $-1 \mathrm{~b}$. The X-ray diffraction pattern (XRD) from Figure $-1 \mathrm{~b}$ shows the cubic phase of aluminum oxide corundum with the chemical formula $\mathrm{Al}_{2} \mathrm{O}_{3}$-corundum. The peaks of the diffractogram appear at $2 \theta=25.68^{\circ} ; 35.24^{\circ} ; 37.85^{\circ} ; 43.49^{\circ} ; 52.68^{\circ} ; 57.58^{\circ} ; 66.64^{\circ}$; and $68.31^{\circ}$ with the respective fields namely (102), (104); (110), (113), (024), (116), (214), and (300) (JCPDS: 431484). The appearance of a diffraction pattern with low intensity at an angle of $33.15^{\circ}$ with the Miller index (111) indicates the presence of $\mathrm{CoO}$ which leads to an amorphous form, because it only has one diffraction pattern which is following JCPDS 42-1300. In addition, two diffraction patterns of low intensity at $2 \theta=$ $37.37^{\circ}$ and $43.361^{\circ}$ are adjacent to the angles of $\mathrm{Al}_{2} \mathrm{O}_{3}$-corundum, which have miller index (111) and (200), respectively. This indicated the presence of $\mathrm{NiO}$ from the $\mathrm{NiCo}(1: 3) / \mathrm{Al}_{2} \mathrm{O}_{3}$ compound (JCPDS 04-0835). The $\mathrm{NiO}$ and $\mathrm{CoO}$ peaks that appear showed that the $\mathrm{Ni}$ and Co metals loaded on the support are still in the form of $\mathrm{NiO}$ and $\mathrm{CoO}$. This is because it has not been reduced to metal, therefore the catalyst used for the dehydrogenation reaction of hydrazine hydrate was reduced by the in-situ process, where the reduction was carried out simultaneously with the reaction process.

Based on JCPDS 15-0806 (Co) and JCPDS 04-0850 (Ni) the NiCo diffraction pattern appeared at the angles of $44.5,51.85$ and $76.90^{\circ}$, respectively, the crystalline diffraction plane (111), (200) and (220). On the other hand, as can be seen in Fig.-1b, there are only two diffraction patterns, namely at an angle of $44.5^{\circ}$ and $76.90^{\circ}$, which indicates the formation of a low-intensity NiCo alloy. The resulting low intensity makes the NiCo alloy lead to a low crystallinity form. ${ }^{19}$

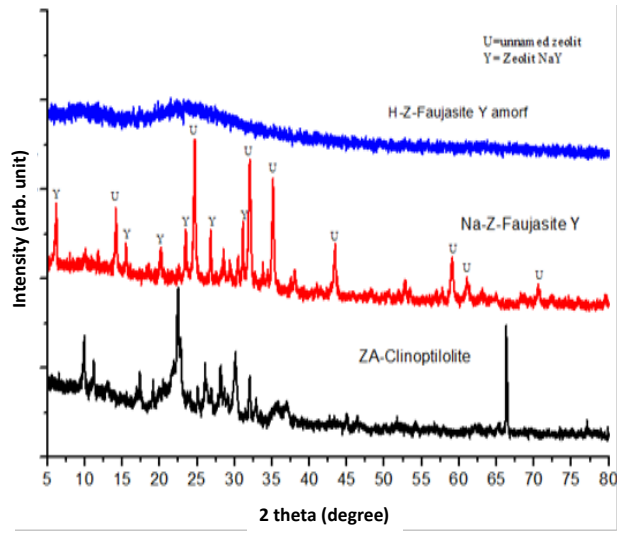

(a)

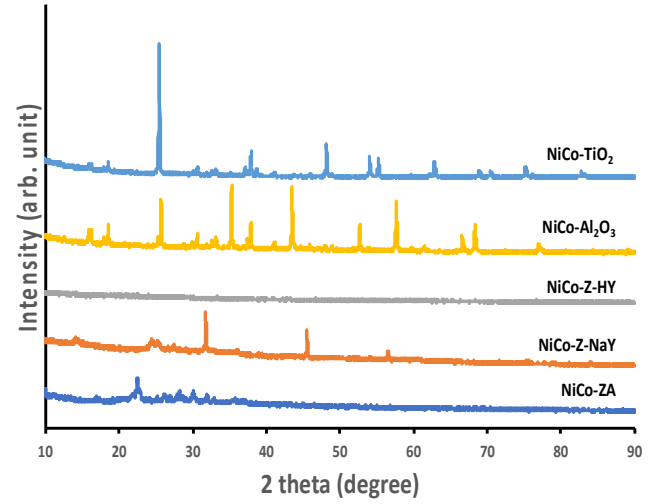

(b)

Fig.-1: The Diffractogram of (a) Zeolite and (b) NiCo Bimetallic Catalyst with Different Support

Figure- $1 \mathrm{~b}$ also shows a typical XRD pattern of anatase $\mathrm{TiO}_{2}$, according to JCPDS 21-1272. The diffraction pattern in Figure - $1 \mathrm{~b}$ was dominant in anatase $\mathrm{TiO}_{2}$, so that the NiCo alloys that are embedded in $\mathrm{TiO}_{2}$ only appear in one diffraction pattern at an angle of $44.88^{\circ}$ with low intensity. The presence of one peak between 44 and $45^{\circ}$ indicates the presence of the NiCo alloy in amorphous form so that the Ni and Co content may produce a very low percentage and the resulted of NiCo purity was also low. The diffraction pattern of NiCo metal alloys (1:3) on zeolite supports, both natural zeolite Lampung clinoptilolite (ZA-clipnoptilolite) and zeolite Na-Faujasite-Y (Na-ZY) and zeolite H-Faujasite-Y (Z-HY) can be seen in Figure -1b. The diffraction pattern of natural zeolite clinoptilolite (ZA-clipnotilolite) with NiCo (1:3)/ZA-clipnoptilolite catalysts experienced a shift in the area of the diffraction peaks and decreased in intensity at an angle of $9.90^{\circ}$; and $22-30^{\circ}$ The shift of the diffractogram peak area and decreased intensity in the NiCo(1:3)/ ZAClipnotilolite catalyst diffraction pattern showed that the NiCo metal alloy was distributed on the pore 
surface of the zeolite. As with the $\mathrm{NiCo}(1: 3) / \mathrm{Z}-\mathrm{NaY}$ catalyst and the $\mathrm{NiCo}(1: 3) / \mathrm{Z}-\mathrm{HY}$ catalyst also experienced a shift in the area of the diffractogram peaks and a decrease in intensity at the angles that are characteristic of Z-NaY and Z-HY supports. The diffraction pattern on the NiCo (1:3)/Z-NaY catalyst at $2 \theta$ $=37.06^{\circ}$ and $53.48^{\circ}$ based on JCPDS 44-0922 shows the presence of an aluminum cobalt nickel phase contained in zeolite Z-NaY. On the other hand, the NiCo (1:3)/Z-HY catalyst when compared to the Z-HY diffraction pattern has decreased the intensity of the peak area at an angle of $23-28^{\circ}$. This showed that the NiCo (1:3)/Z-HY catalyst leads to an amorphous form.

$\mathrm{XRF}$ analysis was used to determine the elemental composition of the catalyst quantitatively. The results are presented in Table -2. The results show that the catalyst supported by zeolite NaY has a decrease in $\mathrm{Si}$ concentration compared with natural zeolite. This is during the synthesis of $\mathrm{Z}-\mathrm{NaY}$, an alkaline fusion process was carried out using $\mathrm{NaOH}$ which is functions as a silica binder, where this process undergoes desilication.

Table -2: XRF Analysis Result

\begin{tabular}{|c|c|c|c|c|c|c|}
\hline \multirow[b]{2}{*}{ No } & \multirow[b]{2}{*}{ Element } & \multicolumn{5}{|c|}{ Concentration $(\%)$} \\
\hline & & $\begin{array}{c}\mathrm{NiCo}(1: 3) \\
/ \mathrm{Al}_{2} \mathrm{O}_{3}\end{array}$ & $\begin{array}{c}\mathrm{NiCo}(1: 3) \\
/ \mathrm{TiO}_{2}\end{array}$ & $\begin{array}{c}\mathrm{NiCo}(1: 3) \\
/ \mathrm{ZA}\end{array}$ & $\begin{array}{c}\mathrm{NiCo}(1: 3) \\
/ \mathrm{Z}-\mathrm{NaY}\end{array}$ & $\begin{array}{c}\mathrm{NiCo}(1: 3) \\
/ \mathrm{Z}-\mathrm{HY}\end{array}$ \\
\hline 1 & $\mathrm{Ni}$ & 7.25 & 4.16 & 8.10 & 7.61 & 7.66 \\
\hline 2 & $\mathrm{Co}$ & 28.40 & 13.26 & 30.82 & 30.77 & 29.23 \\
\hline 3 & $\mathrm{Al}$ & 49.51 & - & 4.79 & 10.17 & 12.84 \\
\hline 4 & $\mathrm{Si}$ & - & - & 26.94 & 17.97 & 23.04 \\
\hline 5 & $\mathrm{Ti}$ & - & 72.88 & - & - & - \\
\hline 6 & $\mathrm{Na}$ & - & - & - & 1.31 & - \\
\hline
\end{tabular}

In the desilication process of the zeolite with alkaline media, the $\mathrm{Si}$ atoms in the $\mathrm{Si}-\mathrm{O}-\mathrm{Si}$ are extracted first in an alkaline treatment compared to $\mathrm{Si}-\mathrm{O}-\mathrm{Al}$. This is due to the presence of $\mathrm{AlO}_{4}{ }^{-}$which is capable to stabilize the surrounding $\mathrm{Si}$ atoms by rejecting $\mathrm{OH}^{-}$. So that $\mathrm{Si}-\mathrm{O}-\mathrm{Al}$ is less likely to be attacked by $\mathrm{OH}-$ than Si-O-Si. ${ }^{20}$ The Na content in Z-NaY in Table-2 shows an exchangeable cation process between $\mathrm{Na}^{+}$ ions in $\mathrm{NaOH}$ with a balancing cation that can be exchanged on the zeolite frame, where $\mathrm{Na}^{+}$cations can increase polarization in the gas adsorption process. The results in Table-2 also show an increase in $\mathrm{Al}$ and $\mathrm{Si}$ in $\mathrm{Z}$-HY supported catalysts, with this increase the $\mathrm{Si} / \mathrm{Al}$ ratio will also increase so that there was a change in the zeolite framework. Based on the resulting data, the Z-HY material composition showed that the exchange of $\mathrm{Na}^{+}$with $\mathrm{H}^{+}$ions was successful because the percentage of $\mathrm{Na}$ content in the Zeolite $\mathrm{HY}$ material was not found. The occurrence of $\mathrm{Ni}$ and Co metals in the material indicates that the NiCo alloys are successfully impregnated into the supports. The XRF analysis results in Table-2 also show the percent impregnated. The ratio of the XRF results is following the impregnation carried out, where the composition contained the results is still $1: 3$.

Catalytic dehydrogenation of hydrous hydrazine was carried out for all the catalyst support system which stated above. The best variation of the ratio of the active catalyst component will be applied with other supports, namely $\mathrm{TiO}_{2}$, natural zeolites, synthetic zeolites $\mathrm{NaY}$ and $\mathrm{HY}$. The conversion comparison between the active components of the NiCo alloy with different ratios can be seen in Figure-2a and $2 \mathrm{~b}$. Figure-2a shows that the $\mathrm{NiCo}(1: 3) / \mathrm{Al}_{2} \mathrm{O}_{3}$ ratio variation results in a higher conversion than other ratio variations. $\mathrm{NiCo}(1: 3) / \mathrm{Al}_{2} \mathrm{O}_{3}$ catalysts get the best results because there was more metal Co content, the higher the Co metal concentration, the higher the conversion obtained. The conversion in catalytic activity is highly dependent on catalyst composition.

The catalyst activity graph is presented in Fig.-2b shows that the $\mathrm{Co} / \mathrm{Al}_{2} \mathrm{O}_{3}$ catalyst has a high turnover frequency (TOF) than the $\mathrm{Ni} / \mathrm{Al}_{2} \mathrm{O}_{3}$ catalyst, with the value of $520.89 \mathrm{~h}^{-1}$ and $77.30 \mathrm{~h}^{-1}$, respectively. In addition, it also shows that the $\mathrm{NiCo}(1: 3) / \mathrm{Al}_{2} \mathrm{O}_{3}$ catalyst also has a high TOF of $503.11 \mathrm{~h}^{-1}$ compared to the NiCo catalyst in the comparison of other ratios. While data show that the TOF value of the $\mathrm{Co} / \mathrm{Al}_{2} \mathrm{O}_{3}$ catalyst was higher than the $\mathrm{NiCo}(1: 3) / \mathrm{Al}_{2} \mathrm{O}_{3}$ catalyst, but the bimetallic catalyst was more selective with the value of $12.48 \%$ and $16.5 \%$, respectively. The strong metal-metal interaction in the bimetallic system can adjust the bond between the reactants and the catalyst surface, thereby stabilizing the transition state and the reaction intermediate, which leads to an increase in catalyst activity. ${ }^{21} \mathrm{NiCo}$ catalyst with a variation 


\section{RASĀYAN J. Chem.}

Vol. 14 | No. 3 |1821-1828| July - September | 2021

of the NiCo ratio (1:3) was used as an active component that will be impregnated on other supports, namely $\mathrm{TiO}_{2}$, natural zeolites, and synthetic zeolites $\mathrm{NaY}$ and $\mathrm{HY}$. NiCo catalysts with various NiCo ratios (1:3) impregnated on various types of supports will also be tested for dehydrogenation hydrazine hydrate for hydrogen formation and analyzed for catalyst characterization.

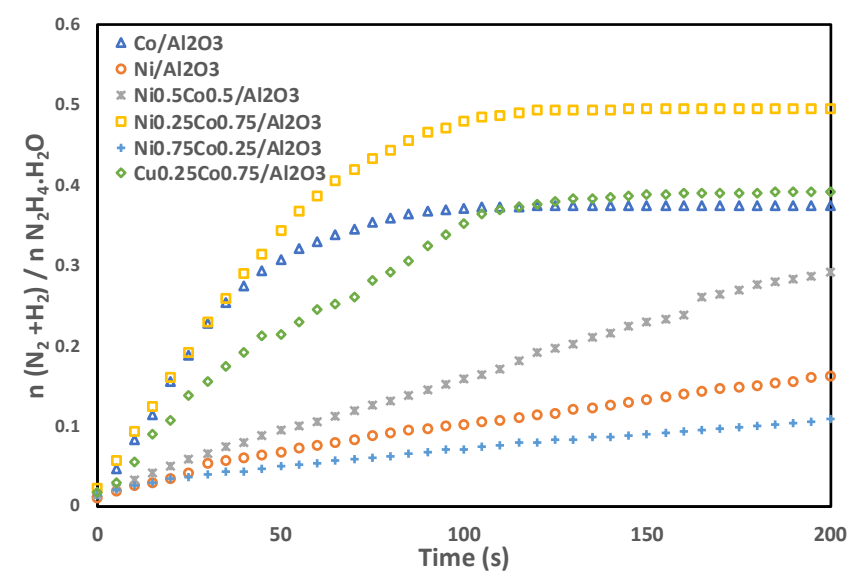

(a)

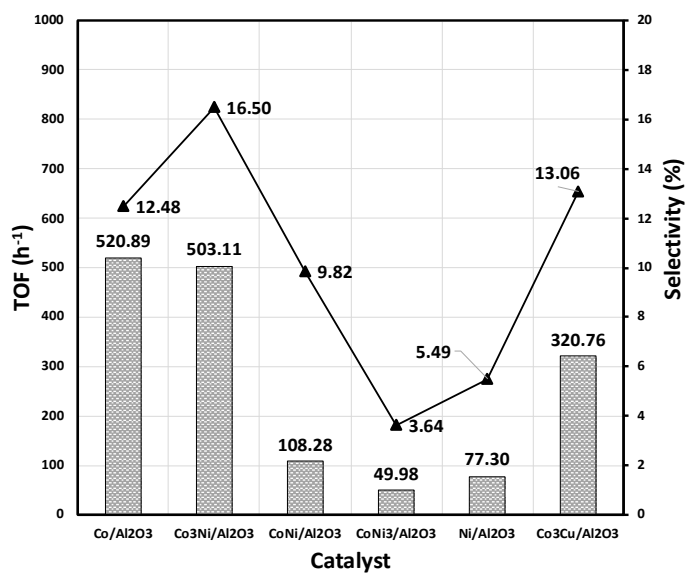

(b)

Fig.-2: (a) Time Profile Decompositions of Hydrazine Monohydrate and (b) TOF and Selectivity Calculation on Different Catalyst Systems.

The data on the catalytic activity results of NiCo catalyst (1:3) which are supported by $\mathrm{TiO}_{2}, \mathrm{Al}_{2} \mathrm{O}_{3}, \mathrm{ZA}$ clinoptilolite, and zeolite synthesis $\mathrm{NaY}$ and HY are seen in Fig.-3a. Variations were studied to determine the effect of zeolite support on hydrazine hydrate dehydrogenation reaction in hydrogen formation and with other support materials such as $\mathrm{Al}_{2} \mathrm{O}_{3}$ and $\mathrm{TiO}_{2}$. Pillai, et al., examined the degree of acidity in $\mathrm{Al}_{2} \mathrm{O}_{3}$ and $\mathrm{TiO}_{2}$, where the results stated that $\mathrm{Al}_{2} \mathrm{O}_{3}$ had the highest degree of acidity, and $\mathrm{TiO}_{2}$ has a basicity property. ${ }^{22}$ Based on the XRF results on the catalyst, according to previous research which states that $\mathrm{Al}_{2} \mathrm{O}_{3}$ has the highest degree of acidity, then the NiCo bimetal catalyst which has a higher $\mathrm{Al}_{2} \mathrm{O}_{3}$ content can be stated to have a high degree of acidity. The level of acidity in the catalyst can affect the resulting conversion and catalyst activity. The activity of the catalyst in the form of frequency turnover (TOF) on this catalyst can be seen in Fig.-3b.

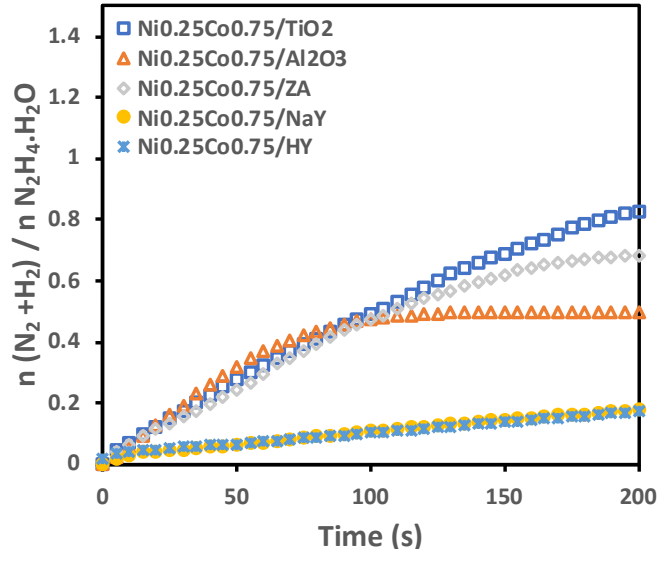

(a)

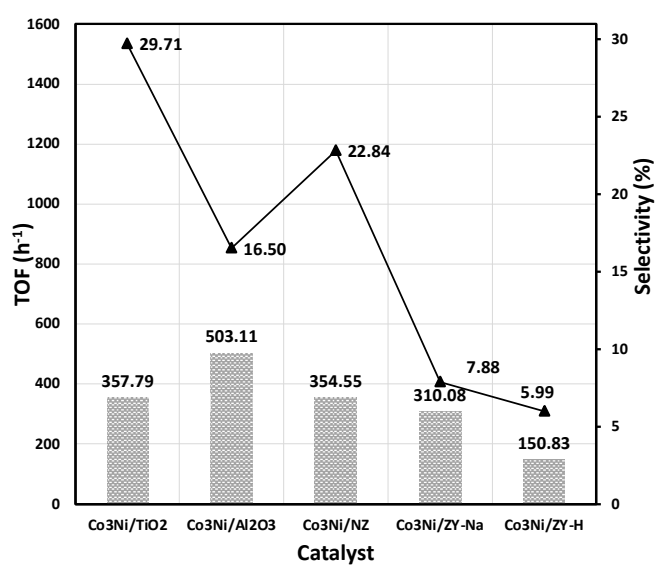

(b)

Fig.-3: (a) Time Profile Decompositions and (b) The Catalyst Activity (TOF h ${ }^{-1}$ ) with Different Support.

The results of the catalyst test with the lowest acidity level had the highest conversion and catalyst activity, namely the $\mathrm{NiCo}(1: 3) / \mathrm{TiO}_{2}$ which obtained a higher conversion at 155 seconds compared to other catalyst support, at $29.71 \%$ selectivity with a TOF value of $357.79 \mathrm{~h}^{-1}$. Based on the analysis, the best catalyst is the $\mathrm{NiCo}(1: 3) / \mathrm{TiO}_{2}$ catalyst, then the temperature variation was carried out in the hydrazine hydrate dehydrogenation reaction to determine the activation energy. 
The result of the hydrogen conversion can be seen in Fig.-4a and Fig.-4b. Figure-4 shows that the $\mathrm{NiCo}(1: 3) / \mathrm{TiO}_{2}$ catalyst at $353 \mathrm{~K}$ has the highest conversion. The selectivity obtained by the NiCo (1: 3) $/ \mathrm{TiO}_{2}$ catalyst at a temperature of $353 \mathrm{~K}$ with a time of 155 seconds is $32.83 \%$. In addition, at $353 \mathrm{~K}$ also produced the best catalytic activity with the TOF of $529.03 \mathrm{~h}^{-1}$, which is shown in Fig.-4a. This suggests that the rate of hydrogen formation increases with increasing reaction temperature, which suggests that a high reaction temperature is useful for increasing the rate of hydrogen generation ${ }^{2}$.

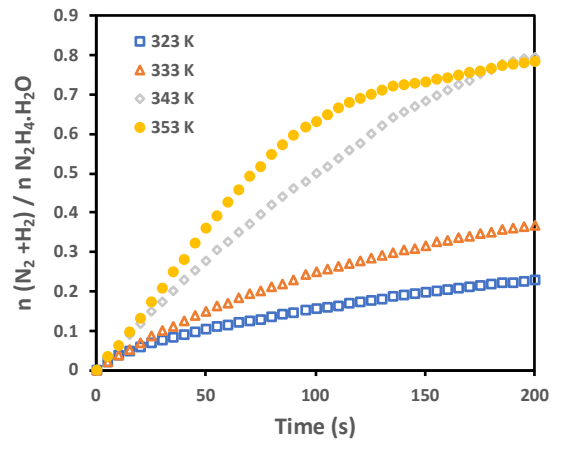

(a)

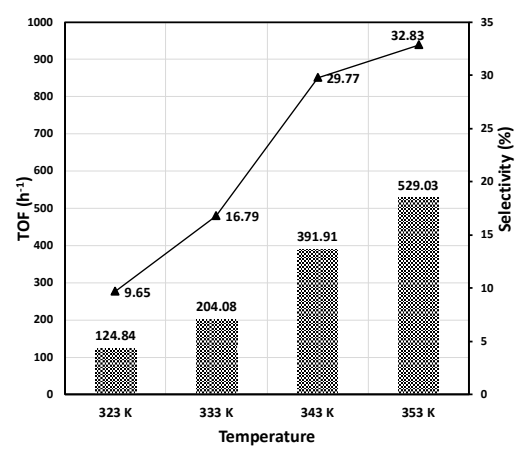

(b)

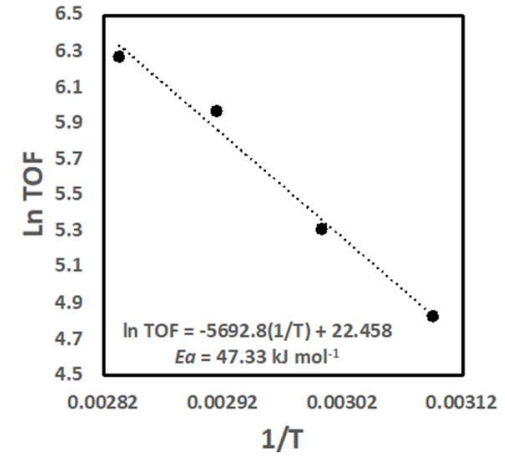

(c)

Fig.-4: (a) Time Profile Decompositions, (b) TOF and Selectivity Graph at a Different Temperature, (c) Arrhenius Plot

The resulting TOF value against temperature variations from 323 to $353 \mathrm{~K}$ on the $\mathrm{NiCo}(1: 3) / \mathrm{TiO}_{2}$ catalyst was used to obtain the value of the activation energy. The activation energy can be found by knowing the rate constant $\mathrm{k}$ which is calculated at a different temperature. The slope of the linear portion of each plot and the value of the linear regression equation were calculated. The Arrhenius plot can be seen in Figure 4(c). Figure -4(c) was plotted the $\mathrm{X}$ value comes from the 1/T calculation and the $\mathrm{Y}$ value comes from the ln TOF calculation as $\ln \mathrm{K}$, and the resulting linear line equation can produce activation energy. The activation energy (Ea) obtained on the $\mathrm{NiCo}(1: 3) / \mathrm{TiO}_{2}$ catalyst was $47.33 \mathrm{~kJ} / \mathrm{mol}$.

\section{CONCLUSION}

This study found that Z-NaY produced from hydrothermal processes has a larger surface area than natural zeolites, namely $88.94 \mathrm{~m}^{2} / \mathrm{g}$. The resulting Z-NaY was crystalline while the Z-HY produced from ionexchange modification was amorphous, but the resulting surface area was larger, which is $162.116 \mathrm{~m}^{2} / \mathrm{g}$. The active metal alloy at the variation of the NiCo ratio (1:3) produces high conversion and the best catalyst activity which is $16.50 \%$ for \pm 5 minutes with a TOF of $503 \mathrm{~h}^{-1}$. The best type of catalyst support is $\mathrm{TiO}_{2}$ $\left(\mathrm{NiCo}(1: 3) / \mathrm{TiO}_{2}\right)$ which produces high conversion and the best catalyst activity of $25.708 \%$ for \pm 5 minutes with a TOF $357.79 \mathrm{~h}^{-1}$. The results of temperature variations on NiCo $(1: 3) / \mathrm{TiO}_{2}$ were done to obtain activation energy with the value of $47.33 \mathrm{~kJ} \mathrm{~mol}^{-1}$.

\section{ACKNOWLEDGEMENT}

The authors would like to thank Universitas Indonesia for funding this research through PUTI Grant with contract number NKB-1973/UN2.RST/HKP.05.00/2020

\section{REFERENCES}

1. G. Cipriani, V. Di Dio, F. Genduso, D. La Cascia, R. Liga, R. Miceli, and G. Ricco Galuzzo, International Journal of Hydrogen Energy, 39, 8482(2014), https://doi.org/10.1016/j.ijhydene.2014.03.174

2. K. Yang, K. Yang, S. Zhang, Y. Luo, Q. Yao, and Z. H. Lu, Journal of Alloys and Compound, 732, 363(2018), https://doi.org/10.1016/j.jallcom.2017.10.241

3. L. He, Y. Huang, A. Wang, Y. Liu, X. Liu, X. Chen, J. J. Delgado, X. Wang, and T. Zhang, Journal of Catalysis. 298, 1(2013). https://doi.org/10.1016/j.jcat.2012.10.012

4. W. Wang, X. Hong, Q. Yao, and Z.H. Lu, Journal of Material Chemistry A, 8, 13694(2020), 
RASĀYAN J. Chem.

Vol. 14 | No. 3 |1821-1828| July - September | 2021

https://doi.org/10.1039/D0TA05322H

5. H. Zou, S. Zhang, X. Hong, Q. Yao, Y. Luo, and Z.H. Lu, Journal of Alloys and Compounds, 835, 155426(2020), https://doi.org/10.1016/j.jallcom.2020.155426

6. J. Chen, H. Zou, Q. Yao, M. Luo, X.G. Li, and Z.H. Lu, Applied Surface Science, 501, 144247(2020), https://doi.org/10.1016/j.apsusc.2019.144247

7. Y. Men, X. Du, G. Cheng, and W. Luo, International Journal of Hydrogen Energy, 42, 27165(2017), https://doi.org/10.1016/j.ijhydene.2017.08.214

8. Y. Chen, L. Wang, Y. Zhai, H. Chen, Y. Dou, J. Li, H. Zheng, and R. Cao, RSC Advances, 7, 32310(2017), https://doi.org/10.1039/C7RA04390B

9. S. K. Singh, A. K. Singh, K. Aranishi, and Q. Xu, Journal of American Chemical Society, 133, 19638(2011), https://doi.org/10.1021/ja208475y

10. W. Kang and A. Varma, Applied Catalysis B: Environment. 220, 409(2018), https://doi.org/10.1016/j.apcatb.2017.08.053

11. Susilawati, T.I. Nasution, and S. Khanifah, Rasayan Journal of Chemistry, 13(3), 1785(2020), https://dx.doi.org/10.31788/RJC.2020.1335678

12. Y.A.B. Neolaka, E.B.S. Kalla, G.A. Malelak, and G. Supriyanto, Rasayan Journal of Chemistry, 11(2), 494(2018), http://dx.doi.org/10.31788/RJC.2018.1121994

13. Y. A. Aubakirov, L. R. Sassykova, Zh. Kh. Tashmukhambetova, F. Zh. Akhmetova, S. Sendilvelan, K.O. Sharipov, Sh. N. Kubekova, A.A. Batyrbayeva, R.N. Azhigulova, R. G. Ryskaliyeva, A.K. Zhussupova and T. S. Abildin, Rasayan Journal of Chemistry, 12(4), 1701(2019), http://dx.doi.org/10.31788/RJC.2019.1245435

14. T. Li, H. Liu, Y. Fan, P. Yuan, G. Shi, X. T. Bi, and X. Bao, Green Chemistry, 14, 3255(2012), https://doi.org/10.1039/C2GC36101A

15. Y. Wang, F. Lin, and W. Pang, Journal of Hazardous Material, 160, 371(2008), https://doi.org/10.1016/j.jhazmat.2008.03.006

16. S. W. Pratomo, F. W. Mahatmanti, and T. Sulistyaningsih, Indonesian Journal of Chemical Science, 6, (2017).

17. M. M. J. Higgins and J. B. Treacy, Collection of Simulated XRD Powder Patterns for Zeolites, (2001).

18. G. Afreen, T. Patra, and S. Upadhyayula, Molecular Catalysis, 441, 122(2017), https://doi.org/10.1016/j.mcat.2017.08.010

19. Z. B. Yu, M. H. Qiao, H. X. Li, and J. F. Deng, Applied Catalysis A: General, 163, 1(1997), https://doi.org/10.1016/S0926-860X(96)00419-X

20. K. Sadowska, A. Wach, Z Olejniczak, P. Kuśtrowski, and J. Datka, Microporous and Mesoporous Material, 167, 82(2013), https://doi.org/10.1016/j.micromeso.2012.03.045

21. Y. Cheng, $\mathrm{X}$. $\mathrm{Wu}$, and $\mathrm{H} . \mathrm{Xu}$, Sustainable Energy and Fuels, 3, 343(2019), https://doi.org/10.1039/C8SE00538A

22. K. R. P. Sabu, K. V. C. Rao, and C. G. R. Nair, Bulletin of Chemical Society of Japan, 64, 1920(1991), https://doi.org/10.1246/bcsj.64.1920

[RJC-6319/2021] 